This section of the programme is the most uneven - speeding through a number of techniques (clone selection, blotting, hybridization, DNA sequencing) would surely leave the student wondering what the techniques are for and not really knowing how to carry them out. No doubt such details come in a later programme, but here the producers should have resisted the temptation to pack in so much detail.

The pace then slows down, as $c$ DNA cloning is dealt with briefly but adequately, but speeds up again as we launch into monoclonal antibodies and start injecting things into Xenopus oocytes. Well, it is an overview; but again I would have been happier had the desire to mention almost every technique been stifled.

The final section largely uses stills with voice-over to try to answer the question: "Why is industry so interested in all this?". Topics include improving the quality of plant proteins, mineral extraction, "improved" bacteria for energy production from plant waste and for degrading pollutants, as well as interferon and insulin production. Much credit is given to genetic engineering (at the molecular level) for doing, or potentially doing, all of these things; but it is, I think, churlish, if not inaccurate, to fail to mention that for centuries plant and animal breeders have been messing around with the genetic constitutions of species in order to "improve" them.

Also included in the final section is a description of how recombinant DNA technology may, and indeed is, being used in the diagnosis of inherited disease. How this is done is very clearly shown including a description of the analysis of DNA taken from chorionic villi using a DNA probe for prenatal diagnosis of a genetic defect.

Overall the programme gives a good indication for what can be done with recombinant DNA. The photography of the techniques is of a high standard, illustrating the advantage of film or videotape over "cold print" for demonstrating methodology, and most of the graphics are clear and straightforward. The speech, too, is clear and should easily be understood by those whose first language is not English. My main criticism is the unevenness of pace in some parts of the programme, but I would expect this to be less of a problem in subsequent tapes dealing with individual techniques in detail.

A little booklet accompanies the videotape and contains many of the graphics in printed form. These diagrams will be useful for students when revising the details of the techniques. However, while the booklet gives a warning that some of the reagents used are hazardous, neither tape nor booklet says that you should get the permission of a genetic manipulation committee before proceeding. Perhaps this comes later.

E.J. Wood is a Senior Lecturer in the Department of Biochemistry, University of Leeds.

\section{On ice and climate}

\author{
Claus U. Hammer
}

The Climatic Record in Polar Ice Sheets. Edited by Gordon de Q. Robin. Cambridge University Press: 1983. Pp.212. £32.50, \$59.50.

GLACIERS move slowly. So, apparently, does the publication of monographs on polar ice sheets. In The Climatic Record in Polar Ice Sheets, an offspring of a workshop held in 1973, the subject is the information to be obtained on past climate from ice sheets, through the past $100,000-150,000$ years with a few excursions further back into the Quaternary. The huge polar ice sheets are indeed slowly moving, frozen libraries of past atmospheric conditions, but the information they contain is written in a detailed, complex language. How far have we come in the translation of that language?

The aim of the workshop was to investigate the validity of data obtained from ice sheets, whether in the form of isotopic composition of ice cores or via measured temperature profiles along the corresponding boreholes. Such studies are complicated by the flow history of the ice, and changes in the isotopic composition of the ice can only in part be interpreted as changes in temperature. The book offers a great deal of detailed information on these problems, and a central much-needed contribution (Chapter 5) is devoted to ice flow and heat transport within the ice sheet.

The general reader may have difficulties getting through this account, though glaciologists will feel more at home. The model calculations presented are exemplified by ice core case-studies, but I suspect that current models and input parameters are not realistic enough to give safe answers; a lot more glacio-meteorological data are needed before climate may be accurately inferred from ice cores.

In other chapters the reader is given a guided tour of the ice library, but I cannot help feeling a little lost: lacking is an introductory chapter to place the enterprise within the general context of the Quaternary. Attempts to this end have been made in a chapter on ocean cores, but a broader discussion of time scales and variability of ocean core data would have been helpful. Nonetheless, the data presented in the book add much to our understanding of salient problems in this area. For example, the total gas content in air bubbles in the ice can indicate old surface elevations of the ice sheets, and surface studies of snow accumulations, temperatures and so on are clearly of importance.

The book's emphasis on the relationship between isotopes and borehole temperature profiles is more a reflection of its origin at a workshop in 1973 than of new developments. While contributions have been updated by the introduction of more recent results, they do not entirely conceal the fact that ten years have passed since the book was conceived. That being said, some of the most important findings in ice-sheetclimatic research since the 1960 s are presented here, among them a number bearing upon still-controversial subjects.

This collection of ice-core data with its discussion of analytical methods is a must for climatic researchers. But to interpret much of the information found in the book such readers may require additional information from the glaciological literature.

Claus U. Hammer is at the Geophysical Isotope Laboratory, University of Copenhagen.

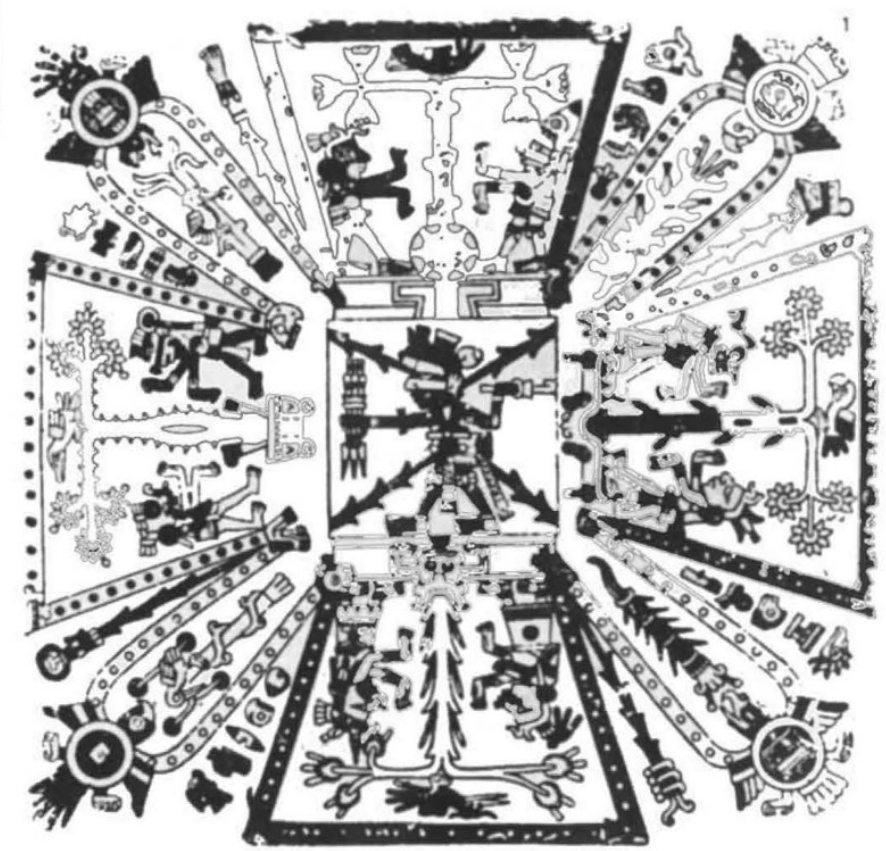

The cosmological plan of the Aztec universe, laid out horizontally. The illustration shows the nine Lords and two hundred and sixty days of the Sacred Calendar assigned to the four cardinal directions, the centre of the universe, and sacred birds and trees. The illustration, reproduced from the Codex Fejervary. Mayer $I$, is taken from Brian M. Fagan's The Aztecs, an illustrated account of early Mexican life and culture. The book is published by W.H. Freeman, price hbk $\$ 27.95, £ 26.95$; pbk $\$ 14.95, £ 13.95$. 